\title{
Examining Indonesian Government Strategies in the Aviation Sector Post Covid-19 Pandemic
}

\author{
Hanna Khairunnisa Adjie ${ }^{1}$, Diana Mutiara Bahari ${ }^{2 *}$ \\ 1,2Master of International Relations, Postgraduate Program, Universitas Muhammadiyah \\ Yogyakarta, Jl. Brawijaya, Kasihan, Bantul, 55183, Indonesia.
}

Received: 2021-09-07; Accepted: 2021-10-25; Published: 2021-10-31

\begin{abstract}
Aviation is an inseparable part of transportation in any country. The aviation sector is one of the sectors most affected by the Covid-19 pandemic. Indirectly, the spread of the Covid-19 virus can occur in airlines, which are the fast transportation options for passengers. Indonesia has taken a policy to stop its aviation sector from reducing the spread of the Covid19 virus and prioritize the health of its citizens. The drastically reduced flight frequency without clarity of time impacts many losses to the aviation industry. The Indonesian government plans a gradual recovery effort in the aviation sector through domestic flights. However, there are concerns from the Indonesian people, as airline passengers who will be traveling, regarding their health safety on flights during the large-scale social distancing period during the Covid-19 pandemic. Therefore, this study will discuss the strategies of the Indonesian government in the aviation sector after the Covid-19 pandemic to still prioritize the health of its citizens. This study uses the theory of the foreign policy decision-making process. The method used in this study is a qualitative based research method. This study concludes that the strategies taken by the Indonesian government include reducing $50 \%$ of passenger capacity to enforce safe distances, sanitizing aircraft, and for prospective passengers to be required to show a certificate of negative Covid-19 results through a PCR swab test or GeNose C19.
\end{abstract}

Keywords: Aviation; Covid-19; Large-Scale Social Restrictions; Policy; Strategy

How to Cite: Adjie, H. K., \& Bahari, D. M. (2021). Examining Indonesian Government Strategies in the Aviation Sector Post Covid-19 Pandemic. Journal of Contemporary Governance and Public Policy, 2(2), 79-91. https://doi.org/10.46507/jcgpp.v2i2.45.

Permalink/DOI: https://doi.org/10.46507/jcgpp.v2i2.45 


\section{Introduction}

On December 31, 2019, the World Health Organization in China received 29 reports of new cases with no identifiable cause of pneumonia in Wuhan. Within one week, the virus was quickly identified as a novel beta-coronavirus called coronaviruses and viral infections called Covid-19. The Coronavirus has spread throughout China in less than a month, even worldwide. WHO declared a health emergency related to Covid-19, which caused 95.000 confirmed cases; almost 3,200 deaths occurred and had spread to 80 countries, one of which was Indonesia (Chen et al., 2020).

The spread of Covid-19 in Indonesia was confirmed by President of Indonesia on March 2, 2020, when two Depok residents tested positive for the Coronavirus. President of Indonesia statement was followed by information from the Japanese government and the New Zealand government regarding other infected cases with the Coronavirus. The Japanese government said that a citizen of his country contracted the Coronavirus after returning from Indonesia. Meanwhile, the New Zealand government also reported that a 60-year-old woman arrived from Iran who tested positive for Corona after spending time in Bali (Jakarta Globe, 2020). After this incident, the spread of the Coronavirus was so massive, reaching 17 provinces in Indonesia. Based on data from the Covid-19 Handling Acceleration Task Force website, the total positive confirmed cases of Covid-19 until June 2020 reached 55.090. In line with this figure, COVID-19 Handling Task Force also confirmed that the number of patients who were declared cured of Covid-19 infection went 23,800, and
2.805 patients died from the virus (BNPB, 2020; Triyadi, 2020).

The rapid spread of the Coronavirus has caused the government to increase awareness by implementing several policies in various sectors to reduce the spread. The government's effort to reduce the spread of the Coronavirus is to urge all people to implement physical

distancing. President Joko Widodo set this appeal based on the WHO recommendation, which expects to reduce the spread of the virus (WHO, 2020). The government has also implemented a large-scale social restriction policy to reinforce the appeal for physical distancing. Largescale social restrictions is the action to restrict certain activities of residents in an area suspected of being infected with Corona Virus Disease 2019 (Covid-19) to prevent the possibility of the spread of the Covid-19 virus (Presiden Republik Indonesia, 2020). Therefore, the Regional Government is expected to carry out large-scale social restrictions for a particular province or city, which are carried out for 14 days and can extend if there is evidence of distribution (Kemenkes, 2020a).

The spread of the Coronavirus spread to several provinces in Indonesia has had a significant impact on the economic sector, influenced by the aviation sector. In line with the large-scale social restrictions policy, the Indonesian government has temporarily banned domestic flights through airports from and to areas that have been determined by the physical distancing and regions included in the red zone. Thus, flight frequency drastically decreased from March to May 2020 without an exact time, which resulted in many losses to the aviation sector and the domestic economy (Rosana \& 
Setiawan, 2020). The decline in aviation sector activity during the Covid-19 pandemic decreased national GDP by $0.18 \%$. Considering the above conditions, the Indonesian government, in this case, the Ministry of Transportation through the Directorate General of Civil Aviation, needs to pay serious attention to efforts to restore the aviation sector in National Economic Recovery through domestic routes.

There are several studies related to the aviation sector during the Covid-19 pandemic. A study (Agustina, Mustopo, Prama, Takwin, \& Tangkudung, 2020) supports efforts to regenerate the Indonesian people's air transportation. There is a need for campaigns and promotions that support air transport services. The change in society's decline in airline use was driven by the feeling of being mistaken when using an airplane because it violated the health, safety norms, and values promoted by the Indonesian government. The study indicates a need for increased social support for air transport services and increased positive attitudes and sentiment towards air force services in the pandemic's era.

The study (Sugiarti, 2021) concludes that the Covid-19 pandemic has profoundly impacted aviation. The Covid-19 pandemic has caused a decrease in the transportation of goods and passengers during the Covid-19 pandemic. In 2019, domestic flights can carry 51,974 tons and 7,298,817 passengers, inversely proportional to 2020 or during the Covid-19 pandemic, which only took 43,586 tons and carried 2,912,040 passengers. As for international flights, airlines can carry 42,638 tons and carry $4,277,218$ passengers in 2019 , and in 2020 only 27,215.2 tons and 800,579 passengers.
A study (Soehardi, Siddha, Hardiyono, Siswanti, \& Hardipamungkas, 2020) states that the spread of Covid-19 in Indonesia, which has caused many casualties, causes concern for foreign and Indonesian tourists. Thus, this impacts a decrease in tourist visits by $58.80 \%$ and $59.96 \%$, while the reduction of Indonesian tourists is $71.98 \%$ and $69.09 \%$. In addition, the outbreak that hit Indonesia also resulted in a decrease in company revenues, which resulted in a reduction in the number of airline employees in Indonesia, such as a reduction of 800 employees of Garuda Group companies and 2,600 employees of Lion Group airlines.

A study (Fathurahman et al., 2020) constructs models and strategies for the recovery of the aviation industry after the Covid-19 pandemic. This study shows that the aviation industry's recovery scenario in Indonesia is divided into three methods: optimistic, moderate, and conservative. The optimistic scenario has a V-shape model. The moderate scenario consists of a U-shape and Prolonged U-shape models, and the conservative scenario consists of Lshape and W-shape models.

From several previous studies related to the aviation sector during the Covid-19 pandemic, this article will analyze the Indonesian government's strategy in the aviation sector after the Covid-19 pandemic. This article has novelty in exposing the Indonesian government's strategy through the aviation sector during large-scale social restrictions pandemic Covid19.

\section{Theoretical Framework}

To analyze the Indonesian government's strategy in the aviation sector, the author uses the Theory of Foreign Policy Making. Decisions 
made in a country's foreign policy are usually strategies to achieve that country's national interests. According to Coplin (2003) it is written that:

"To be interested in why states behave as they do interest area, we have to be interested in why their leaders make the decision. However, it would be a mistake to think that foreign policymakers act in a vacuum. On the contrary, any given foreign policy act may be viewed as the result of three board categories of considerations affecting the foreign policy decision-makers state. The first is domestic politics within the foreign policy decision makes the state. The second is the economic and military capability of the state. The third is the international context, the particular position in which his state finds itself, especially to other states in the system (Coplin, 2003). "

To understand the above explanation, William D. Coplin described a scheme to facilitate and understand the foreign decisionmaking process and explained how the three determinants of foreign policy are interrelated, which are then used as the basis for the head of state to determine his foreign policy. The schematic is as illustrated in Figure 1.

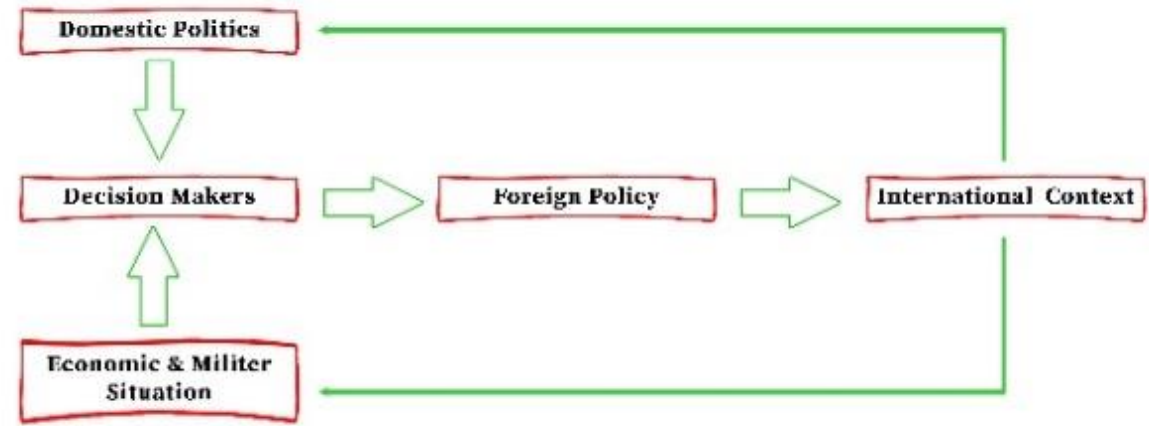

Figure 1 Schematic Theory of Foreign Policy Making Source: Coplin (2003)

According to the scheme, the Indonesian government's strategy in the aviation sector can be analyzed through two factors, according to William D. Coplin, which can influence the head of state to determine a country's policies. First is the international context. In this case, the international context is that the Coronavirus originating from China has spread worldwide, including Indonesia. The massive spread of the Coronavirus in Indonesia has significantly impacted Indonesia's economic situation, where the aviation sector contributes to the domestic economy. The spread of Covid-19 in the aviation sector can be seen from the existence of a policy for members to stop domestic and international flight schedules for safety and public health reasons. Thus, it can be said that the second factor in determining a country's policy is the country's economic situation.

The two factors that influence decision-making, namely the international context and the country's economic situation, are 
related to one another. The Coronavirus, which spread to Indonesia, caused the suspension of flight activities for various airlines, resulting in a decline in the domestic economy. Therefore, the Ministry of Transportation also plays a significant role in the recovery of the national economy by implementing a series of strategies, especially in the aviation sector.

\section{Research Methods}

The author uses a qualitative study of the concept with the descriptive method in writing this article. This method is usually used to explain the problem in this research because this method is a research method consisting of systematic, factual, and accurate depiction of facts and relationships between the phenomena studied. The qualitative method is the most comprehensive method to describe the application of the Indonesian government in the aviation sector after the Covid-19 pandemic.

The author focuses the article on a literature study by collecting data and information from various literature relating to the cases discussed. This article uses a secondary data analysis approach, including books, articles, newspapers, and other sources covering the main research issues. The data obtained will then be analyzed qualitatively, producing descriptive data in written words.

\section{Results and Discussion}

\section{Covid-19 in Indonesia}

Globalization makes global community interaction more intense and higher. Therefore, Covid-19, which was initially only in Wuhan, China, quickly spread and infected many countries in the world, including Europe, America, Asia, and Indonesia. At the end of February 2020, the Indonesian government denied that this new virus had spread in Indonesia. However, on March 2, 2020, President Joko Widodo announced that two Depok residents had tested positive for the Coronavirus. The President also explained that the two Depok residents were a woman and her daughter who had previously been in contact with a Japanese national who turned out to be tested positive for the Coronavirus during an examination in Malaysia. In addition, two other cases have contributed to the spread of the Coronavirus in Indonesia. First, the Japanese government said that a citizen of his country contracted the Coronavirus after returning from Indonesia. Second, New Zealand also reported that a 60-year-old woman arrived from Iran who tested positive for Corona after spending time in Bali (Jakarta Globe, 2020). After this incident, the spread of the Coronavirus was so massive, reaching 17 provinces in Indonesia.

Based on the spread of cases of the Coronavirus, which were tested positive for Indonesia's infection, at least it has three distribution clusters. The first cluster is the "Jakarta cluster," considering that the first case and up to the ninth case is in Jakarta. The second cluster is imported case or transmission from abroad. The circumstances of transmission that occurred in Indonesia came from the Diamond Princess Ship, and 14 patients came from residents who returned to Indonesia after traveling abroad. The third cluster is classified as a separate new cluster because of one case where the origin of transmission is unknown (R. D. Putri, 2020). 


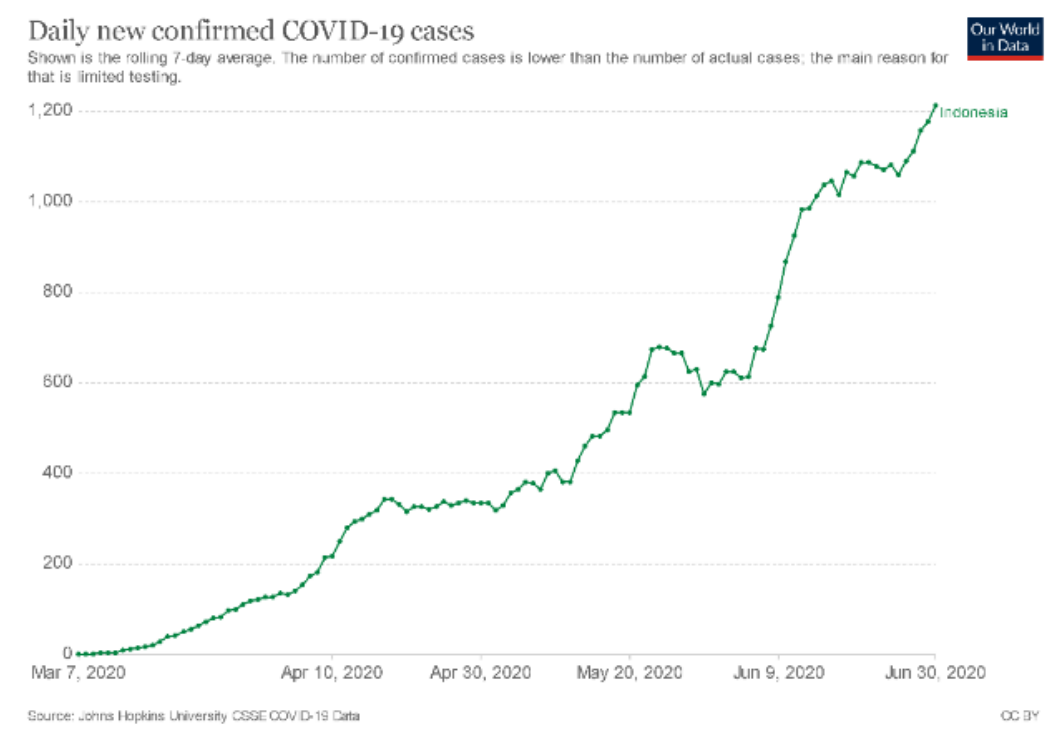

Figure 2 Daily New Confirmed Covid-19 Cases in Indonesia Source: Our World in Data (2020b)

The Ministry of Health reports a significant increase every day in the number of confirmed patients infected with Covid-19 (see figure 2). Until June 2020, there were 56.385 confirmed cases Covid19. In addition to the active case- patients, patients diagnosed with Covid-19 were 24.806 patients, and 2,876 patients would otherwise die from the virus. So, now 28,703 patients are still being treated (Kemenkes, 2020b).

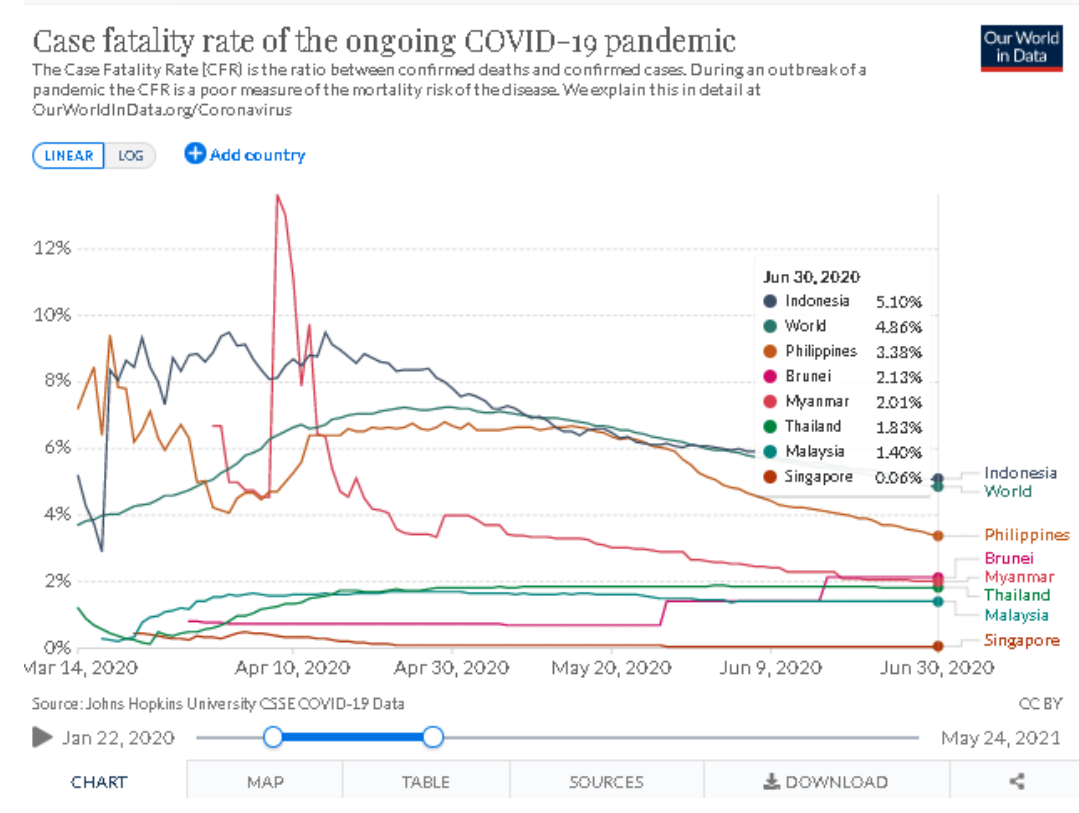

Figure 3 Case Fatality Rate of Ongoing Source: Our World in Data, (2020a)

According to data obtained from the European Centers for Disease Control and Prevention (CDC) in June
2020 , the number of deaths caused by Covid-19 in Indonesia is the highest in Southeast Asia, with a case fatality

Hanna Khairunnisa Adjie, Diana Mutiara Bahari/Examining Indonesian Government Strategies in the Aviation Sector Post Covid-19 Pandemic 
rate (CFR) of $5.10 \%$, while the average number - global average $4.86 \%$ according to WHO count (see figure 2). CFR is calculated based on the ratio between confirmed deaths and confirmed cases by a country (Our World in Data, 2020a).

Several factors have contributed to the high death rate caused by being infected with Covid19 , such as a lack of education to the public about Coronavirus, hospital unpreparedness in handling Covid-19 patients, and limited medical equipment Covid-19 confirmed patients and protective equipment self for health workers. So that victims die from the community and health workers would fall to Coronavirus (Ekawati, 2020).

In Indonesia, the Covid-19 outbreak worsens, followed by increasing cases every day. The government increases awareness by establishing

a physical distancing appeal following WHO directives. To reinforce the appeal for physical distancing and also following Law Number 6 of 2018 concerning Health Quarantine, the Indonesian government established a policy through Decree No 022868 A, namely Government Regulation Number 21 of 2020, concerning Large-Scale Social Restrictions in the Context of Accelerated Handling of Corona Virus Disease 2019 (Covid19).

The government implemented the large-scale social restrictions policy based on epidemiological considerations and the magnitude of the threat posed by the Coronavirus. Implementing largescale social restrictions by the government was because Indonesia had met the criteria based on these government regulations, there is the number of cases and deaths due to particular outbreaks, the existence of a rapid and significant spread of the virus to several regions, and an epidemiological link with similar incidents in the other country (Presiden Republik Indonesia, 2020).

\section{The Impact of Covid-19 on the Aviation Sector}

Since early 2020, many countries have closed international flight activities to reduce the spread of the Covid-19 virus. With the highest CFR in Southeast Asia, Indonesia has stipulated a policy prohibiting commercial flights carrying passengers on international and domestic routes to areas with implemented large-scale social restrictions and sites with red zone status until an undetermined time limit. This policy was established to reduce the Covid-19 virus spread and prioritize the safety and health of the Indonesian people. This policy is based on the Regulation of the Minister of Transportation of the Republic of Indonesia Number PM 25 of 2020 concerning Transportation Control during the Idul Fitri 1441 Hijriah Homecoming Period in the Context of Preventing the Spread of Corona Virus Disease 2019 (Covid19). In addition, the policy of stopping activities in the aviation sector is to support the appeal for physical distancing and the large-scale social restrictions policy that has been established by President Joko Widodo (Kementerian Perhubungan, 2020).

At the global level, the International Civil Aviation Organization (ICAO) noted that there had been a decrease several passenger numbers by 59 to $60 \%$ or more than 800 million passengers, and the estimated potential losses that the aviation sector would accept amounted to USD 150 billion (ICAO, 2021a). Meanwhile, The International Air Transport Association (IATA) 
calculated that the decline in airline revenue last year reached $54.7 \%$ year on year. At the national level, the unclear time limit for the prohibition of flight activities set by the Ministry of Transportation has also resulted in broad impacts, such as a decrease in foreign tourists and the number of domestic flights. Data from the Central Statistics Agency (BPS) noted that foreign tourist arrivals in March 2020 decreased by $64.11 \%$ compared to the number of visits in March 2019, and the number of foreign tourist arrivals in March 2020 also decreased by $45.50 \%$ when compared to February 2020 (BPS, 2020).

The aviation sector experienced a negative impact due to Covid-19, in which the flow of passengers and cargo experienced a drastic decline from March 2020 to April 2020. The decline in demand from the aviation sector and foreign tourists impacted national

GDP. Based on the Second Quarter Economic Growth Report by BPS, the aviation sector experienced a drop of $80.23 \%$, more significant than the first quarter of $13.21 \%$. This condition caused the performance of various airlines in Indonesia to deteriorate, such as Garuda Indonesia, which suffered a loss of IDR 10.2 trillion. Apart from that, the aviation sector also contributed to the decline in the contribution to national GDP. In 2019, the aviation sector contributed $1.63 \%$ to the national GDP in the second quarter. At the beginning of the Covid-19 pandemic in Indonesia, the aviation sector's contribution to national GDP decreased to $0.028 \%$ (Adnan, 2020).

The BPS report shows that the number of passengers on domestic and international airlines has decreased cumulatively from January 2020 to June 2020. The number of domestic air passengers recorded at
18.4 million people, or a decrease of $49.67 \%$ from the 2019 period, 36.5 million people. Meanwhile, airline passengers abroad have decreased by $61.66 \%$, or as much as 3.4 million people (Agustina et al., 2020). The factor of Indonesian citizens themselves also supported the decline in the flow of airline passengers. This condition is because indirectly, the spread of the Covid-19 virus occurs in air transportation, which is the choice of fast transportation for most Indonesians. A report from the Indonesian Transportation Community shows that $63.6 \%$ of respondents are not sure that they will not infect Covid-16 on an airline. Even the public considers the most significant risk of contracting Covid19 while on a plane. (Nursalikah, 2020).

\section{The Indonesian government's Strategy for the Aviation Sector}

The decline in airlines' use harmed the aviation sector business, the economy, and other related aspects. Considering the above conditions, the Indonesian government needs to save national airlines. The aviation sector plays a dominant role as a global supply chain that can drive economic growth when the pandemic ends. Therefore, the Ministry of Transportation, through the Directorate General of Civil Aviation, needs to pay serious attention to efforts to restore the aviation sector in the context of efforts to restore the National Economy through a series of strategies so that the aviation sector can revive (CSE Aviation, 2020).

Considering the many losses suffered by the aviation sector, the Ministry of Transportation is working to restore the aviation sector, relying on domestic aviation to recover the national economy. The 
Circular of the Task Force supports this for Handling Covid-19 No. 7 of 2020 concerning Travel Criteria and Requirements for People in the Adaptation Period for New Habits Towards a Productive and Safe Society of Covid-19 using flights by complying with health protocols. To support this circular, the Ministry of Transportation issued a Minister of Transportation Regulation Number 41 of 2020, which contains Amendments to Minister of Transportation Regulation Number 18 of $2020 \quad$ concerning Transportation Control in the context of Preventing the Spread of Covid19 (Ma'arif, 2020; C. A. Putri, 2020). The Minister of Transportation, Budi Karya Sumadi, stated that transportation control through the Minister of Transportation focuses on health. The Indonesian government has implemented several strategies in the aviation sector through these two things. The public, both transportation officers and passengers, can remain productive but remain safe from the risk of Covid-19 transmission.

The first strategy is to set the maximum capacity at the airport to be $50 \%$. Minister of Transportation Regulation 41/2020 stipulates that the maximum airline passenger capacity is $70 \%$ of the total seating capacity to implement physical distancing. In more detail, the second strategy, specifically in Minister of Transportation Regulation $41 / 2020$, requires airlines to ensure that aircraft remain in hygienic conditions. All facilities and infrastructure, mainly those frequently touched by passengers, include door handles, handrails, airplane seats, toilets, cabins, eating utensils, and regular air conditioning disinfection following the sanitation and hygiene standards for flights
WHO. For ventilation in air transportation, ensure air circulation with exhaust routinely or at least periodically sufficiently so that fine droplets and aerosols floating in the air are expected to be removed from the space inside the airport (ICAO, 2021b).

IATA recommends that airlines ensure that the AC and HighEfficiency Particulate Air (HEPA) in the aircraft air circulation system are always good. The HEPA filter is replaced periodically according to the aircraft manufacturer's recommendations. The HEPA filter is an air filter to keep air quality clean with a filtration capability of $85 \%$ and removal efficiency of $99.995 \%$. The air circulation system in the aircraft changes every 2-3 minutes, including in the well-ventilated classification. When combined with the use of masks, barriers between passengers or face shields, and the proper application of other health protocols, the risk of Covid19 transmission will be reduced (Arora, Tuchen, Nazemi, \& Blessing, 2021; Sampurna et al., 2020)

The third strategy of the Indonesian government requires every passenger to complete documents as a condition of flight, namely by bringing a health certificate and free from Covid-19 through a PCR test with negative results whose samples taken within a maximum period of $2 \times 24$ hours before departure. Other than that, the community can be using swab antigen or test Ge-Nose C19 methods with non-reactive results-the samples were taken within 24 hours before departure (Anwar, 2020).

In addition, the Indonesian government urges airline officers, airport officers, and airline passengers to adhere to health protocols, such as wearing masks, using face shields, and 
applying physical distancing while on duty or while flying. The statement supported by the existence of a metaanalysis study of 172 studies between 2003-2020 regarding the transmission of SARS, MERS, and Covid-19 shows that the application of physical distancing of 1 meter or more can reduce the risk of transmission compared to applying less than 1 meter. The research also shows that masks and face or eye shields can protect people from infection with the virus. This research is in line with changes in WHO policy regarding the use of masks to prevent the transmission of Covid-19 (Chu et al., 2020).

\section{Conclusion}

In a short time, Covid19 originating from China, has spread all over the world. The virus has caused many fatalities worldwide, so WHO declares that Covid-19 is a global pandemic. Indonesia is one of the countries affected by the spread of the Coronavirus. The number of casualties increasing every day has led the government to appeal to the broader community to carry out physical distancing, balanced with improved personal hygiene to reduce the spread of the Coronavirus. The government has also established a Large-Scale Social Restriction policy in all sectors to optimize the physical distancing appeal.

In addition to falling casualties, Covid-19 caused the fall of the aviation sector to a policy to stop all flight activities. This policy has a broad impact, such as a decrease in foreign tourists, a reduction in passengers, a decrease in airline revenue, and a reduction in the aviation sector's contribution to national GDP. Thus, the Indonesian government must determine various national airline rescue strategies through the Ministry of Transportation, considering the aviation sector plays a dominant role as a global supply chain. The strategy undertaken by the Indonesian government is to determine the maximum capacity at the airport not to be more than $50 \%$, the maximum airline passenger capacity of $70 \%$ of the total seating capacity to implement physical distancing, airlines are required to ensure the aircraft remains in hygienic condition and obliges every passenger to complete documents stating that they are healthy and free of Covid-19 as a condition of the flight.

\section{Acknowledgments}

The authors are grateful to express gratitude to all those who had the pleasure to work during this research.

\section{References}

Adnan, R. S. (2020). Pandemi Covid19: Dampak Sektor Penerbangan. Jakarta.

Agustina, A., Mustopo, W. I., Prama, H. S., Takwin, B., \& Tangkudung, E. (2020). Peningkatan Perilaku Pengguna Angkutan Udara. Jakarta.

Anwar, M. C. (2020). Syarat Penerbangan Saat New Normal, Ini Detailnya. Retrieved 12 September 2021, from CNBC Indonesia website: https://www.cnbcindonesia.c om/news/202006151421274-165430/syaratpenerbangan-saat-newnormal-ini-detailnya

Arora, M., Tuchen, S., Nazemi, M., \& Blessing, L. (2021). Airport pandemic response: An assessment of impacts and strategies after one year with COVID-19. Transportation Research Interdisciplinary Perspectives, 11(100449), 1- 
13.

https://doi.org/10.1016/j.trip. 2021.100449

BNPB. (2020). Situasi Virus Corona. BPS. (2020). Perkembangan Pariwisata dan Transportasi Nasional Maret 2020. In Badan Pusat Statistik. Jakarta.

Chen, N., Zhou, M., Dong, X., Qu, J., Gong, F., Han, Y., ... Zhang, L. (2020). Epidemiological and clinical characteristics of 99 cases of 2019 novel coronavirus pneumonia in Wuhan, China: a descriptive study. The Lancet, 395(10223), 507-513. https://doi.org/10.1016/S014 0-6736(20)30211-7

Chu, D. K., Akl, E. A., Duda, S., Solo, K., Yaacoub, S., Schünemann, H. J., ... Reinap, M. (2020). Physical distancing, face masks, and eye protection to prevent personto-person transmission of SARS-CoV-2 and COVID-19: a systematic review and metaanalysis. The Lancet, 395(10242), 1973-1987. https://doi.org/10.1016/S014 0-6736(20)31142-9

Coplin, W. D. (2003). Pengantar Politik Internasional: Suatu Telaah Teoritis (2nd ed.; M. Marbun, Ed.). Bandung: Sinar Baru Algesindo.

CSE Aviation. (2020). Kebijakan Pemerintah dalam mengatasi Covid 19 di Bidang Industri Penerbangan Nasional. Retrieved 12 June 2021, from CSE Aviation website: http://www.cseaviation.biz/?p=902

Ekawati, A. (2020). Why Does Indonesia Have a High Covid19 Mortality Rate? Retrieved 21 October 2021, from DW website: https://www.dw.com/en/why -does-indonesia-have-a-high- covid-19-mortality-rate/a52947235

Fathurahman, H., Berawi, M. A., Sulistyarini, I., Kusuma, A., Nasution, Y., \& Komarudin. (2020). Post COVID-19 Recovery Models and Strategies for Aviation in Indonesia. International Journal of Technology, 11(6), 1265-1274.

https://doi.org/10.14716/ijte ch.v11i6.4455

ICAO. (2021a). Effects of Novel Coronavirus (COVID-19) on Civil Aviation: Economic Impact Analysis. In International Civil Aviation Organization. Canada.

ICAO. (2021b). Indonesia Update on Aviation Operational Measure Related To Covid-19 Pandemic. In International Civil Aviation Organization. Canada.

Jakarta Globe. (2020). Indonesia Confirms First Coronavirus Cases in Its Territory. Retrieved 29 June 2021, from Jakarta Globe website: https://jakartaglobe.id/news/ indonesia-confirms-firstcoronavirus-cases-in-itsterritory/

Kemenkes. (2020a). Peraturan Menteri Kesehatan Republik Indonesia Nomor 9 Tahun 2020 Tentang Pedoman Pembatasan Sosial Berskala Besar Dalam Rangka Percepatan Penanganan Corona Virus Disease 2019 (Covid-19). In Kementerian Kesehatan Republik Indonesia.

Kemenkes. (2020b). Situasi Terkini Perkembangan Coronavirus Disease (COVID-19) 1 Juli 2020. Retrieved 12 September 2021, from Kementerian Kesehatan Republik Indonesia website: 
https://infeksiemerging.kemk es.go.id/situasi-infeksi-

emerging/situasi-terkiniperkembangan-coronavirusdisease-covid-19-1-juli-2021

Kementerian

Perhubungan.

Peraturan Menteri

Perhubungan Republik

Indonesia Nomor PM 25

Tahun $2020 \quad$ Tentang

Pengendalian Transportasi

Selama Masa Mudik Idul Fitri

1441 Hijriah Dalam Rangka

Pencegahan Penyebaran

Corona Virus Disease 2019

(Covid-19). , (2020). Jakarta, Indonesia.

Ma'arif, N. (2020). Terbitkan Revisi Permenhub Saat New Normal, Kemenhub Ubah Aturan Ini. Retrieved 19 June 2021, from Detik News website: https://news.detik.com/berita /d-5046753/terbitkan-revisipermenhub-saat-new-normalkemenhub-ubah-aturan-ini

Nursalikah, A. (2020). Survei: Masyarakat Masih Anggap Naik Pesawat Berbahaya. Retrieved 21 September 2021, from Republika website: https://www.republika.co.id/ berita/qgn9az366/surveimasyarakat-masih-anggapnaik-pesawat-berbahaya

Our World in Data. (2020a). Case Fatality Rate of The Ongoing Covid-19 Pandemic. Retrieved 20 October 2021, from Our World In Data website: https://ourworldindata.org/gr apher/covid-cfr-exemplars

Our World in Data. (2020b). Coronavirus (COVID-19) Cases. Retrieved 2 July 2021, from Our World In Data website:

https://ourworldindata.org/c oronavirus

Presiden Republik Indonesia. Peraturan Pemerintah
Republik Indonesia Nomor 21

Tahun $2020 \quad$ Tentang

Pembatasan Sosial Berskala

Besar Dalam Rangka

Percepatan Penanganan

Corona Virus Disease 2019

(Covid-19). , (2020). Jakarta, Indonesia.

Putri, C. A. (2020). Ini Aturan \& Syarat Naik Pesawat di Tengah Pandemi Covid-19. Retrieved 12 August 2021, from CNBC Indonesia website: https://www.cnbcindonesia.c om/market/20200613181829 -17-165153/ini-aturan-syaratnaik-pesawat-di-tengahpandemi-covid-19

Putri, R. D. (2020). Kronologi Penularan Pasien Positif Corona Covid-19 di Indonesia. Retrieved 21 April 2021, from Tirto.ID website: https://tirto.id/kronologipenularan-pasien-positifcorona-covid-19-di-indonesiaeD6x

Rosana, F. C., \& Setiawan, K. (2020). Kemenhub Tutup Seluruh Penerbangan Penumpang Dalam dan Luar Negeri. Retrieved 21 June 2021, from Tempo website: https://bisnis.tempo.co/read/ 1334866/kemenhub-tutupseluruh-penerbanganpenumpang-dalam-dan-luarnegeri

Sampurna, B., Mulyawan, W., Wibawanti, R., Nahry, Iswardhani, T., \& Ariawan, I. (2020). Policy Brief: Standar Kesehatan di Pesawat Udara dan Prasarana Transportasi Udara dalam Masa Pandemi Covid-19. Jakarta.

Soehardi, S., Siddha, A., Hardiyono, H., Siswanti, T., \& Hardipamungkas, N. E. (2020). Pengaruh Pandemik Covid-19 Terhadap Wisatawan 
Mancanegara Dan Nusantara Serta Karyawan Perusahaan Penerbangan Di Indonesia. Jurnal Ilmiah Manajemen Ubhara, 2(2), 46-60. https://doi.org/10.31599/jmu .v2i2.769

Sugiarti. (2021). Analisis Dampak Covid-19 Terhadap Penerbangan di Indonesia. Jurnal Mitra Manajemen, 12(1), 113-121.

Triyadi, B. (2020). Update Corona 29 Juni 2020: Total Pasien Positif Corona Covid-19 Menjadi 55.092. Retrieved 1 July 2021, from Liputan6 website: https://www.liputan6.com/bo la/read/4291732/updatecorona-29-juni-2020-totalpasien-positif-corona-covid19-menjadi-55092

WHO. (2020). Coronavirus disease (COVID-19) advice for the public. Retrieved 21 October 2021, from World Health Organization website: https://www.who.int/emerge ncies/diseases/novelcoronavirus-2019/advice-forpublic\#: :text=Avoid crowds and close contact,when you cough or sneeze.

(C) 2021 by the Authors. Submitted for possible open access publication under the terms and conditions of the Creative Commons Attribution- ShareAlike (CC BY SA) license (https://creativecommons.org/licenses/by-sa/4.0/). 